\section{CORN MARKET INTEGRATION IN PORFIRIAN MEXICO*}

Rafael Dobado ${ }^{\dagger}$ and Gustavo A. Marrero ${ }^{\ddagger}$

First version September 2002. This version October 2003

${ }^{*}$ We are grateful to the following for help and advice: David Rockefeller Center for Latin American Studies, Colegio Complutense en Harvard, John Coatsworth, Aurora Gómez, Enrique Llopis, Graciela Marquez, Teodosio Perez, Jeffrey Williamson, participants in the seminars of CIDE (Manco)

${ }_{\dagger}^{\dagger}$ Depatamento de Historia Económica, UCM, Campus de Somosaguas, 28223 Madrid, Spain. ‡Dado@ccee.ucm.es

Economía Cuantitativa, UCM. Campus de Somosaguas, 28223 Madrid, Spain. gustavom@ccee.ucm.es

\section{CORN MARKET INTEGRATION IN PORFIRIAN MEXICO}

\section{ABSTRACT:}

This paper deals with a polemic and relevant aspect of the economic history of Porfirian Mexico: the integration of agricultural domestic markets. Since corn was the staple product of the commercial agricultural sector and also the main subsistence crop, it is the protagonist of this story. Panel techniques, similar to those used by Barro and Sala-i-Martín (1992), are applied to a price convergence model. Our analysis reveals that Mexico was not an exception in the international panorama of market integration in late $19^{t h}$ and early $20^{\text {th }}$ centuries [O'Rourke and Williamson (1999)]. Although still incomplete on the eve of the Mexican Revolution, corn market integration substantially increased during the Porfiriato and ended up further than estimated by Kuntz (1995a, 1995b, 1996, 1999a and 1999b). Railroads were not only indispensable to the economic growth of Mexico, as Coatsworth (1984) showed, in particular to the export sector, but they also played a positive and significant role in the process of corn market integration.

Keywords: Porfirian Mexico, market integration, railroads, price convergence and panel data.

JEL Classification: N16, N56, O13, C33 


\section{Introduction}

In contrast with a long tradition of economic history studies focused on the increasing participation of Mexico in the international economy during the Porfiriato (1876, this work deals with a relevant and debatable aspect of the domestic sector: the integration of agricultural markets. This issue is closely connected with the role that railroads, the fundamental innovation in transport during the period, played in Mexican economy.

It is our goal to contribute to the joint study of both topics, and to that of a decisive period of Mexican modern history. Convergence of prices is considered a genuine manifestation of market integration. Since corn was the staple of commercial farming, as well as the main subsistence crop [Coatsworth (1990)], it deserves to play the leading role in any story about the integration of agricultural markets in pre-industrial Mexico. We hypothesize that: a) given the Mexican geography, railroads inevitably had to give an impulse to the economic integration of the Mexican states; b) as a result, interstate differentials in corn prices might have experienced a substantial reduction during the pax porfiriana. This hypothesis had not yet been statistically tested in the literature. Through panel techniques, following the methodology of Barro and Sala-i-Martin (1990, 1992 and 1995), we analyze the convergence of corn prices across Mexican states and territories -hereinafter statesbetween 1885 and 1908. It is our main conclusion that interstate differentials in corn prices substantially decreased in Porfirian Mexico and that railroads played a significant and positive role in the process of convergence. Thus, on the eve of the Mexican Revolution, corn market integration had reached a historical maximum.

The authoritative research conducted by Coatsworth (1979 and 1984) established a new interpretation of the relations between railroads, economic growth and markets in Porfirian Mexico. Although the backward linkages resulting from the operation of railroads were scarce, or null, their contribution to the economic growth of the period in terms of social savings was "crucial": no less than $50 \%$ of the increase in per capita product between 1880 and 1910. Thus, railroads were "indispensable" for economic growth in Mexico. Summerhill (1997) has emphasized the "unprecedented by international standards" importance of Mexican -and Brazilianrailroads to the transition to economic growth by the end of the nineteenth century. Nevertheless, Coatsworth's opinions about the impact of railroads on the Mexican domestic sector are less "optimistic". Echoes of the formerly influential dependenlately criticized by Haber (1997), are perceptible in this point Main beneficiaries of the new possibilities offered by the improvement in overland trans- port were firms involved in import-export activities, foreign mining companies in particular. Railroads are then inseparable from the increasing export orientation of the Mexican econony and the parallel change in its output mix. This picture implies that the domestic sector of the Mexican economy, in spite of its larger size, could only make a relatively minor use of railroads. Therefore there is little reason to expect that agricultural markets integration across Mexican states should have progressed significantly.

The rather "pessimistic" view of Coatsworth has been revised by Kuntz (1995a 1995b, 1996, 1999a and 1999b) and Riguzzi (1999). All in all they put forward a basically "optimistic" reconsideration of the impact of railroads on the domestic economic integration of Mexico. A closer examination of the traffic (origin, destination, composition, short lines, etc.) reveals that: a) far from exclusively reinforcing or creating export oriented enclaves, the railroad network linked the main and most dynamic production and consumption centers; b) exports only represented a small fraction of total freight. Hence the idea that railroads gave an impulse to agricultural market integration across Mexican states is perfectly plausible. In fact, Kuntz (1995a) shows that corn, wheat, as well as other agricultural products intended for the domestic market, accounted for a significant part of the Ferrocarril Central shipments between 1884 and 1907. However, Kuntz (1999b) claims that corn, the only product that could have led the process of national market integration was too cheap to fully exploit the advantages of the new mean of transportation, in spite of the relatively very rapid decrease in its specific fares. Thus, the national market remained "fragmented". ${ }^{1}$

The said "optimism" about the role played by railroads is not a completely novel idea. As Gómez Galbarriato has recently pointed out,${ }^{2}$ Calderón (1965) had already put forward an essentially "optimistic" version of the effects of railroads on the integration of the domestic sector. "Optimistic" is also Cerruti's (1992) view on the positive consequences of railroads for the articulation at regional, national and international levels of the dynamic "north system" of states. ${ }^{3}$

1 "On account of the magnitude of its production and the generalized character of its consumption, corn could have behaved as the product leading the formation of a national market of agricultural products; but owing to the conditions under which it was cultivated and its low price, it proved to be unable to play that role. This combination turned out to be fateful for the 19th century Mexican economy: it obstructed the formation of wide and deep commercial circuits; it hindered the economy's specialization, and it kept a considerable part of the population outside the marketplace." [Kuntz (1999b, p. 480)]. Translated from Spanish by the authors.

${ }^{3}$ Cerruti's (1992) "north system" consists of the states of Coahuila, Nuevo León y Tamaulipas 
To some extent, this paper attempts to take a step further into finding the answer to one of the puzzles in Mexican economic history that has been identified by Maurer (1999). According to this author, "the railroads appear to have contributed mightily to the nation's economic growth in the late $19^{\text {th }}$ and early $20^{\text {th }}$ centuries". ${ }^{4}$ Testing in a statically rigorous way the falsifiable hypothesis of the railroads impulse to corn prices equalization in Porfirian Mexico, we hope to reinforce Maurer's confidence in the accuracy of his "apparent optimism". Additionally, this author has recalled "the relative dearth of economically literate studies of agriculture in the Nineteenth Century". ${ }^{5}$

From the methodological point of view, our analysis is original since it relies on the estimation of a panel data model. ${ }^{6}$ Our strategy has consisted in studying the convergence of corn prices across the 30 states composing the Mexican Republic between 1885 and 1908. Prices used are those published by Instituto Nacional de Estadística, Geografía e Informática -hereinafter INEGI- (1985). As is more often than not the case in economic history research, the pre-statistical criteria leading the original gathering of those prices make them probably far from perfect. But some imperfections do not justify its global rejection. Moreover, after close examination of the results obtained from unprejudiced work with them, we find that they may be affected at most only by punctual deficiencies that do not seriously distort the general picture of the corn prices convergence process

The rest of the paper is organized as follows: section 2 presents a first exploration of the panel data set; in section 3, we formulate a simple model of price convergence and show some preliminary results; in section 4 we analyze the relationship between railroads and the convergence process; conclusions and extensions appear in section 5 .

as well as important part of San Luís Potosí, Zacatecas, Durango y Chihuahua.

${ }^{4}$ Maurer, 1999, p. 31

${ }^{6}$ Our approach connects with an increasing international scholarship in the field of the integration of national markets. The interesting findinos of a "first generation" of scholars were mostly based on rather simple statistical tools [Metzer (1974), Hurd (1975) and Rothenberg (1981)]. On the contrary, some authors among those of the "second generation" use the much more sophisticated techniques represented by time series analysis [Roehner (1994), Chevet (1996), Persson (1999), Ejrnaes and Persson (2000) and Llopis and Jerez (2001)].

\section{A first exploration of data}

This section begins with a geographical approach to prices. Map 1 depicts the distribution of prices across Mexican states in 1885-1889. ${ }^{7}$

\section{[INSERT MAP 1 ABOUT HERE]}

It shows a clear pattern: expensive corn is a Northern phenomenon with the only exception of Chiapas, in the South. In most states, the respective corn prices are lower than the national average. Differences in prices among states may be considerable: a factor of 5 between the most expensive state and the cheapest one (Baja California and Campeche, respectively); a factor of 4 between the three most expensive states and the three cheapest ones (Baja California, Sonora and Chiapas and Campeche, Colima and Tepic -currently Nayarit-, respectively).

\section{[INSERT MAP 2 ABOUT HERE]}

Map 2 shows the variation in prices between 1885-1889 and 1904-1908. Corn prices follow a peculiar pattern of change. In general, corn prices decrease in all previously expensive states whereas they increase in the initially cheap states or experience a relatively small change in the rest of states. This pattern brought about significant changes in the geography of prices. In 1904-1908, the geographical distribution of prices -see Map 3- was still heterogeneous, but a process of equalization had already been under way for some time.

\section{[INSERT MAP 3 ABOUT HERE]}

The aggregate situation in 1904-1908 results from a number of different trajectories originating from 1885. For the sake of simplicity, Figure 1 shows three single representative trajectories: Baja California (downward trend), Mexico (moving closely around the national simple average) and Tepic (upward trend).

\section{[INSERT FIGURE 1 ABOUT HERE]}

Figure 1 shows striking differences in corn prices across states at the beginning of the period under consideration and their gradual reduction in the course of time. However, behind the apparent reduction in price dispersion we find a basic dissimilarity: some of the trajectories depicted on Figure 1 (i.e., Baja California and Tepic)

${ }^{7}$ In this section, unless otherwise indicated, prices are always relative to the Republic average. 
may be considered as signs of a tendency towards convergence in some of the Mexican regions, while that of Mexico suggests that other regions might have already constituted an integrated corn market. This mixed situation reflects the different starting-off times in the race for closer integration in a country so big and segmented as Mexico.

Following with this first exploration of data, Figure 2 is intended to show the $\beta$-convergence in the cross section of states, that is, whether or not prices in the lower-priced states grew faster than they did in the higher-priced states. Given the existence of a negative and statistically significant relationship between the initial price level and price growth, the hypothesis of $\beta$-convergence cannot be ruled out.

\section{[INSERT FIGURE 2 ABOUT HERE]}

However, $\beta$-convergence is a necessary -but not sufficient- condition for $\sigma$-convergence [Barro and Sala-i-Martín (1995)]. But market integration -either national [Metzer (1974) and Hurd (1975)] or international [O'Rourke and Williamson (2000) and Findlay and O'Rourke (2001)]- requires the decrease in price dispersion. Therefore, we test for $\sigma$-convergence -see Figure 3. Figure 3 reveals the existence of $\sigma$-convergence: between 1885 and 1908, the dispersion of corn prices across Mexican states almost halved.

\section{[INSERT FIGURE 3 ABOUT HERE]}

By 1908, the dispersion was still high but not so much as to be considered a strange case. In fact, since late $19^{\text {th }}$ century corn price dispersion in Mexico was similar to that of the USA, while its reduction in 1885-1908 had been even faster -see Figure $4{ }^{8}$ Certainly, the physical dimension of the USA market is much bigger, but the Mexican northern neighbor enjoyed a more developed economy in which transportation faced less technical and geographical obstacles.

\section{[INSERT FIGURE 4 ABOUT HERE]}

${ }^{8}$ USA corn prices have been taken from United States Department of Agriculture (1917). States included are those for which there are continuous data from 1869 to 1915 (Alabama, Arkansas California, Connecticut, Delaware, Florida, Georgia, Illinois, Indiana, Iowa, Kansas, Kentucky,

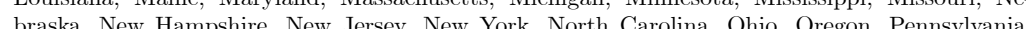
Rhode Island, South Carolina, Tennessee, Texas, Vermont, Virginia, Wisconsin and Virginia) Working with 40 stetes (the 36 above mentioned plus Colorado, Noth Dakota, South Dakota and Utah) with data on corn prices for 1885-1908, results are basically identical.
At the same time, when compared with Spain, Mexican dispersion appears to be always substantially wider -see Figure $4 .^{9}$ However, Spanish dispersion of wheat prices was influenced by more favorable geographical features (500000 square kilometers versus 2 millions and a rounded shape that permitted an intense coastal navigation) and the availability of a nation-wide railroad network since the 1860's. As the comparison with Spain and the USA suggests, the Mexican case is not a peculiar one. ${ }^{10}$

\subsection{Regions and convergence}

In the late $19^{\text {th }}$ and early $20^{\text {th }}$ century Mexico was -it still is- a very heterogeneous country. Differences across regions in terms of geography, economy, and ethnicity were enormous. Consequently, it is possible to consider a priori that the participation of the various regions in the integration process should be uneven. The simple fact that the railroad network did not cover the whole country comes in support of that hypothesis. Thus, we proceed in this section by studying the convergence of corn prices across and within groups of states. These groups in which Mexico is divided are those considered by Bassols (1998), ${ }^{11}$ Esquivel $(1999)^{12}$ and INEGI $(1985) .{ }^{13}$ We work with three alternative divisions of Mexican geography to mini-

${ }^{9}$ Sources of Spanish data are Sánchez Albornoz (1975) and Grupo de Estudios de Historia Rural (1980). They cover the 48 provinces in peninsular Spain and Balearic Islands. For every year from 1856 to 1889, the series include all the provis. Afer ${ }^{10} \mathrm{M}($ erover, ap at fion its

tart, it is coincident with numerous national experiof the second half of the $19^{\text {th }}$ century, as well as with the international one [O'Rourke and Williamson (1999)].

${ }^{11}$ North-western region: Baja California, Sinaloa, Sonora and Tepic. Northern region: Chihuahua, Cohauila, Durango, San Luís Potosí and Zacatecas. North-eastern region: Nuevo León and Tamaulipas. Central-western region: Aguascalientes, Colima, Guanajuato, Jalisco and Michoacán. Central-eastern region: Distrito Federal, Hidalgo, México, Morelos, Puebla, Querétaro y Yucatán peninsula region: Campeche and Yucatán.

${ }^{12}$ Capital: Distrito Federal and México. Center: Hidalgo, Morelos, Puebla and Tlaxcala. CenterNorth: Aguacaliantes, Durango, Querétaro, San Luís Potosí and Zacatecas. Gulf: Campeche, Tabasco, Veracruz and Yucatán. North: Baja California, Chihuahua, Coahuila, Nuevo León, Sonora and Tamaulipas. Pacific: Colima, Jalisco, Sinaloa and Tepic. South: Chiapas, Guerrero, Michoacán and Oaxaca.

North: Chihuahua, Coahuila, Durango, Nuevo León, San Luís Potosí and Tamaulipas. Gulf Campeche, Tabasco, Veracruz and Yucatán. Northern Pacific: Baja California, Sinaloa, Sonora and Tepic. Southern Pacific: Chiapas, Colima, Guerrero and Oaxaca. Centre: Aguascalientes, 
mize the bias that might result from the grouping of states. We find evidence both in favor of $\beta$-convergence and $\sigma$-convergence of corn prices across Mexican regions -see Figure 5 and Figure 6 .

\section{[INSERT FIGURE 5 ABOUT HERE]}

\section{[INSERT FIGURE 6 ABOUT HERE]}

Between 1885 and 1908, a clear process of equalization in regional prices had taken place. An interesting -and complementary- picture emerges if we look at convergence within groups. Once again, results are consistent no matter which geographical division of Mexico is considered. Not surprisingly, the circumstances and the pace of the convergence in corn prices widely differs within groups of states.

Three different patterns may be identified. First, regions such as Yucatan, according to Bassols classification, and Gulf, in those of Esquivel and INEGI, show practically no $\sigma$-convergence. These coefficients of variation are initially high and decline very slightly or nothing at all. Second, a central area (Bassols's Central-eastern region, Esquivel's and INEGI's Central regions and Esquivel's Central-northern region) is characterized by a relatively low initial level of dispersion and slow progress in $\sigma$-convergence afterwards. Finally, the rest of regions always shows a more or less high level of initial dispersion and different rhythms of $\sigma$-convergence. In INEGIS's Southern Pacific, Bassol's Southern and North-eastern and Esquivel's Pacific regions, the fall in dispersion was especially steep. In short, with the exception of Yucatan and Gulf groups, dispersion of corn prices within groups was already low by the mid 1880s or it decreased at different -never too slow- paces in subsequent years.

The complexity of some regional trajectories is also perceptible through the existence of: a) a fairly integrated "economy of frontier" constituted by Mexican and American border states; ${ }^{14}$ and b) a weaker integration between the two geographical extremes of the Mexican Republic. ${ }^{15}$

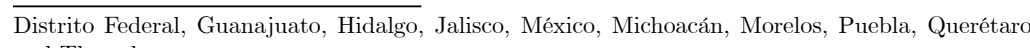
and Tlaxcala.

The slope of the $\beta$-convergence equation is -0.033 , with the t-statistic of 5.303 , a $R$-square coefficient of 0.800 and the coefficient of variation falling from $45 \%$ in $1885-1886$ to $25 \%$ in 1907 15. Arizona is excluded because data are not available.

${ }^{5}$ The slope of the $\beta$-convergence equation is -0.028 , with a standard deviation of 3.042 , a $R$ in 1906-1908. We are considering in thient of variation falling from $51 \%$ in 1885-1887 to $37 \%$ Coahuila, Chibuabe, Tamaulipas, Chiapss, Campeche and Yucatan.
The picture of the Mexican corn market emerging from this first exploration of data is that of equalization in prices across states. Thus, the increasing integration of the domestic market for the main and cheapest agricultural commodity as that observed in the countries participating in the globalization process of the last decades of the $19^{\text {th }}$ century also applies in Mexico. We also observe different patterns at sub-national level: some central regions seem to be integrated before 1885, others experience a more or less rapid convergence -even within a transnational "economy of frontier"- while southeastern states do not converge at all. Hence, inter-regional heterogeneity is a feature of the corn market integration process in Porfirian Mexico. Interestingly enough, the internal coherence of the national panorama is not seriously affected by abnormal, disturbing data. This fact increases our confidence in the data set we are using. However, the relatively simple statistical techniques used so far does not make it possible to find an answer to some relevant questions, i.e., which are the sources of the inter-regional heterogeneity?, what is the role of railroads in the integration process? Therefore we turn to panel data techniques in the next section.

\section{A model of convergence}

We begin by briefly describing the convergence model and first estimations. Next, we focus on steady-state heterogeneity. We postpone the discussion about the relationship between railroads and the integration process to the next section.

The methodology used in this study is similar to the one proposed by Barro and Sala-i-Martín (1990, 1992 and 1995). The econometric model is as follows:

$$
\begin{aligned}
\Delta p_{i, t} & =\alpha_{i}-\beta_{i} p_{i, t-1}+\varepsilon_{i, t}, \\
p_{i, t} & =\ln \left(P_{i t} / \bar{P}_{t}\right), i=1,2, \ldots, 30 ; t=2,3, \ldots, 24, \\
\bar{P}_{t} & =\frac{1}{I} \sum_{i=1}^{30} P_{i, t}, \text { and } p_{i, 1} \text { given for all } i
\end{aligned}
$$

where 30 and 24 are, respectively, the cross-section and the time dimension of the panel, $P_{i, t}$ is the corn price for the $i^{t h}$ state at period $t$, and $\bar{P}_{t}$ is the corn price average for the Republic at period $t$; therefore, $p_{i, t}$ is the relative corn price with respect to the Republic average at period $t$ for the $i^{t h}$ state. $\beta_{i}$ measures the reaction of the current price growth rate to past corn price level; $\alpha_{i}$ is a $1 \mathrm{x} 1$ scalar representing the effects of those variables peculiar to the $i^{t h}$ state, which are assumed to be constant 
over time, but they might differ across states. The error term $\varepsilon_{i, t}$ is a stochastic input, peculiar to each state and time period, representing the effect of omitted variables that directly affect the growth rate of prices.

A steady state is defined as an equilibrium path where relative prices remain constant over time. Imposing $\varepsilon_{i, t}=0$ and $p_{i, t}=p_{i, t-1}=p_{i}^{*}$ for all $i, t$ in (1), it results that

$$
p_{i}^{*}=\alpha_{i} / \beta_{i}, \text { for all } i=1,2, \ldots, 30 .
$$

These steady states are stable or unstable depending on $\beta_{i}$. Values of $\beta_{i}$ closer to 1 are associated with a fast convergence process; values of $\beta_{i}$ approaching 0 indicate slower and monotonic convergence; finally, values of $\beta_{i}$ close to 2 show also slower convergence, although accompanied by oscillating behavior. Being $\beta_{i} \in(0,2)$, those states with $\alpha_{i}=0$ are converging on the Republic average, while those with $\alpha_{i}>(<) 0$ are converging above (below) the Republic average.

\subsection{Preliminary convergence results}

The specification of the convergence model (1) responds to a logical sequence [Hsiao (1986)]: first we check whether or not the fixed effect model is appropriated; ${ }^{16}$ second, we reject the existence of common fixed effects across states; ${ }^{17}$ finally, we also reject that slopes are equal for all states. ${ }^{18}$ Maps 4 and 5 respectively depict the heterogeneity in steady states and speeds of convergence across Mexican states.

\section{[INSERT MAP 4 ABOUT HERE]}

[INSERT MAP 5 ABOUT HERE]

Table 1 summarizes the estimation of several econometric models. Just for illustrative purposes, the first column shows the results of model (1) with common $\alpha$ and $\beta$ for all states. The second column shows the fixed-effect model, with common ${ }^{16} \mathrm{We}$ use the Hausman (1978) test to discriminate between the stochastic and deterministic nature of $\alpha_{i}$ in (1).

The p-value of the suitable Wald $F$-test is 0,0001 .

${ }^{18}$ The p-value of the suitable Wald $F$-test is 0,001 . In the convergence literature, it is common and we must consider this fact in the econometric model to be more accurate in the convergence analysis. $\beta$ and different $\alpha$. The rest of columns shows alternative models that are described below.

\section{[INSERT TABLE 1 ABOUT HERE]}

In all cases, the estimated levels of $\beta$ reinforce the $\beta$-convergence hypothesis: the price of corn in states where it was relatively far below its own steady state in 1885 tended to grow faster than in states where the price was initially closer to its steady state and viceversa. However, according to previous results, we do not find evidence in favor of: a) absolute convergence, for it implies a common level of price which all states were approaching; and b) identical speeds of convergence across Mexican states. These findings reinforce the picture of heterogeneity across regions and states already pointed in section 2.1 .

\subsection{Steady-state heterogeneity}

Since we have found strong evidence against the unconditional convergence hypothesis and in favor of the conditional one, the steady-state heterogeneity must be seriously taken into consideration. Arguably, some intelligible pattern might underlie this steady-state heterogeneity: likely, states with similar geographical and economic characteristics were approaching nearby steady states -see Map 4. With only a few exceptions, Map 4 shows a picture that closely resembles that of a nearly perfect center-periphery structure: states converging on the Republic average or slightly below are located in a wide, almost vertically-oriented, central strip, including from Nuevo Leon and Tamaulipas at the top to Michoacan and Guerrero at the bottom; states converging on the highest steady states draw two compact areas "surrounding" the central strip; states converging on the lowest steady states are small and scarcely populated and situated in both Pacific and Caribbean shores. In Table 2 Mexican states are classified according to their similarities in estimated steady states. ${ }^{19}$ This classification shows a slightly different picture from -although consistent with- that was depicted in Map 4.

\footnotetext{
${ }^{19} \mathrm{We}$ classify steady-states, $s$, following a statistical criteria. From (1), and setting different $\alpha$ and $\beta$ for each state, $\hat{s}_{i}=\hat{\alpha}_{i} / \beta_{i}$ for all $i=1,2, \ldots .30$. Its sample average is $\bar{s}=-0,056$ and its standard deviation is $\hat{\sigma}_{s}=0,217$. According to the Jarque-Bera test, the series of $\hat{s}_{i}$ is normally distributed (the p-value is 0,48 ). Hence, if $\hat{s}_{i}>\bar{s}+\hat{\sigma}_{s}$ (a $85 \%$ one-tail confidence bound), the $i$-th state belongs to the highest group; if $\hat{s}_{i} \in\left[\bar{s}+0,5 \sigma_{s} ; \bar{s}+\sigma_{s}\right)$, the $i$-th state belongs to the higher group; if $\hat{s}_{i} \in\left[\bar{s}-\hat{\sigma}_{s} ; \bar{s}-0,5 \hat{\sigma}_{s}\right)$, to the lower group, and if $\hat{s}_{i}<\bar{s}-\hat{\sigma}_{s}$ to the lowest group. Those states with $\hat{s}_{i} \in\left[\bar{s}-0,5 \hat{\sigma}_{s} ; \bar{s}+0,5 \hat{\sigma}_{s}\right]$ belong to the group converging on the sample average.
} 


\section{[INSERT TABLE 2 ABOUT HERE]}

This sort of heterogeneity may be captured in model (1), adding four regional dummies (we call this model in Table 1 "dummy group"): i) lowest $_{i}=1$, with $i$ equals to Tepic, Campeche and Colima, and zero otherwise; ii) $l o w_{i}=1$, with $i$ equals to Tabasco, Zacatecas, Jalisco, Michoacán, Morelos and Guanajuato, and zero otherwise; iii) $h i g h_{i}=1$, with $i$ equals to Yucatan, Coahuila, Puebla, Hidalgo and Oaxaca, and zero otherwise; and iv) highest ${ }_{i}=1$, with $i$ associated with Veracruz, Chiapas, Sonora and Baja California, and zero otherwise. The resulting model is

$\Delta p_{i, t}=\alpha_{1}+\alpha_{2} \cdot$ lowest $_{i}+\alpha_{3} \cdot$ low $_{i}+\alpha_{4} \cdot$ high $_{i}+\alpha_{5} \cdot$ highest $_{i}-\beta p_{i, t-1}+\varepsilon_{i, t}^{(3)}$,

The estimation of (3) shows -see column 3 in Table 1- that many central -loosely defined- states (such as Guerrero, Aguascalientes, Mexico, DF, etc.) were converging to the Republic average or very close to it, while corn prices in the group of "small and coastal states" (such as Tepic, Campeche and Colima) were moving towards a much lower steady state (40\%-60\%) than that of the "central region". Other states (such as Baja California, Chihuahua, Sonora, Veracruz, etc.) were converging on a very high steady state ( $40 \%$ above the Republic average). Certainly, these differences are far from negligible but they were significantly lower than those existing circa $1885 .{ }^{20}$

${ }^{20}$ Even though an analysis in depth is outside the limits of this work, steady-states heterogeneity deserves some exploration. It seems reasonable to expect some interaction between marke conditions (supply and demand) and steady-state levels within states. However, because of the limitations of the data available, we found it difficult to correctly measure the market conditions associated with a given state. We have information on production and population circa 1907 for each state $\left(Y_{i}\right.$ and $N_{i}$, respectively, for $\left.i=1,2, \ldots, 30\right)$. However, data for consumption are not available Assuming that, in terms of corn, Mexico may be considered a closed economy, total corn production -in per capita units- must be pretty close to consumption. Thus, we can compute the ratio of total production to total population, which must be similar to the total consumption/population ratio, let's it call $X$. If we multiply $X$ by each state's population, we have a 'proxy' of consumption for each state, let's it call $C_{i}$. Hence, now we have data to construct a 'proxy' for production per capita surplus for each state: $\left(Y_{i}-C_{i}\right) / N_{i}$. Circa 1907, states producing important surplus of corn were Guerrero, Mexico, Morelos, Guanajuato, Nuevo Leon, Michoacan and Campeche, while Baja California, Sonora, Distrito Federal, Coahuila, Oaxaca and Puebla show deficits. We found that this 'proxy' is an additional significant variable in explaining the corn price growth rate. Therefore, as expected, surplus are, on average, associated with lower steady-state.

\section{Railroads and the integration process}

In Porfirian Mexico, as was the rule rather than the exception in the countries involved in the growing international economic integration during the second half of the $19^{\text {th }}$ century, prices of the main agricultural product experienced a convergence process. However, as shown in the preceding section, this process was of a peculiar kind: Mexican states converged on different price levels at various speeds of convergence. In this section, we examine the role of railroads in the particular process of corn market integration experienced of the Porfirian Mexico.

O'Rourke and Williamson (1999) have emphasized the important role of declining transport costs within national markets "for both the development of national economies and the world economy" ${ }^{21}$ The contribution of railroads to market integration in the USA, Russia, India, Germany or France is well documented [O'Rourke and Williamson (1999)]. In Porfirian Mexico, the most conspicuous transport innovation was the comparatively late and rapid construction of the railroad network: 1,100 kilometers in 1880 compared with 20,000 in $1910 .{ }^{22}$ Coatsworth's (1984) "geographical conspiracy" (absence of cheap alternatives and location of most populated areas far from both shores) explains the enormous impact of railroads on transport costs. $^{23}$

However, apart from the general "pessimistic" opinion of Coatsworth (1984), not too much analytical work -as Kuntz (1999a) has pointed out- has been devoted to the role of railroads in the integration of a national market for agricultural products in Mexico. Certainly, recent research by Kuntz (1995a, 1995b, 1996, 1999a and 1999b) and Riguzzi (1999) show an "optimistic" view of railroads as an important factor in market integration. However, this "optimism" is only conditional because the exercise on the "potential contribution" of railroads to corn market integration done by Kuntz (1999b) concludes with a rather "pessimistic" view. The low price of corn implied a low "tolerance" of corn to transport costs that limited the extension of the market. Her estimation of the "effective contribution" is also "pessimistic" as far as corn is concerned: only $20 \%$ of the domestic production plus imports was transported

${ }^{21}$ O'Rourke and Williamson, 1999, p. 41 .

${ }^{22}$ Coatsworth, 1984, p. 36

${ }^{23}$ Towards 1889 , the cost of transport of agricultural products by railroad generally halved those of the cheapest alternative option [Kuntz (1999b, p. 478)]. One more indication of the potential of railroads for market integration in Mexico comes from these data: circa 1850, corn consumed in Guanajuato was usually produced within a radius of about 55 kilometers of the town; a longer distance raised transportation costs up to $40 \%$ of the final price [Bushnell and Macaulay (1989, p. $68)]$ 
through railroads in 1907. Kunzt's "pessimism" about corn is in contradiction with our findings in favor of a generalized trend towards price equalization across Mexican states. It is also opposed to the unambiguously positive role played by railroads in market integration in other countries.

Our attempt to clear up this contradiction begins by introducing railroads in our empirical framework. We have not been able to find out any clear relationship between railroads and steady states: for instance, the one of Tabasco was among the lowest while that of Baja California was well above the national average; Veracruz, Puebla, Hidalgo, Mexico and Federal District, all of them with a relatively early presence of railroads, show a relatively wide range of steady states. However, the geography depicted in Map 5 suggests that the timing and the scope of the diffusion of railroads across Mexico should be considered in the explanation of the interstate variability of speeds of convergence. Thus, we try to capture the effect of railroads on convergence speeds by estimating the dummy railroad model,

$$
\Delta p_{i, t}=\alpha_{i}-\beta_{1} p_{i, t-1}-\beta_{2} \cdot \operatorname{rail}_{i} \cdot p_{i, t-1}-\beta_{3} \cdot \operatorname{rail}_{i} \cdot p_{i, t-1}+\varepsilon_{i, t}^{(4)},
$$

where rail0 and rail1 are railroad-dummies, with rail $_{i}=1$, for $i$ associated with states with a railroad before 1885 (Aguascalientes, Chihuahua, Distrito Federal, Durango, Guanajuato, Hidalgo, Jalisco, Mexico, Michoacán, Morelos, Puebla, Queretaro, Tlaxcala, Veracruz and Zacatecas), and zero otherwise; rail $_{i}=1$, for $i$ associated with states where the railroad was build and/or connected with the main network between 1885 and 1908 (Chiapas, Coahuila, Colima, Guerrero, Nuevo León, Oaxaca, San Luis Potosi, Tamaulipas and Tepic) and zero otherwise [Florescano (1983)]. Parameters in (4) turn to be highly significant -see column 4 in Table 1.

In order to obtain more precise estimations of the $\beta$, we combine models (3) and $(4)$,

$$
\Delta p_{i, t}=\alpha_{1}+\alpha_{2} \cdot \text { lowest }_{i}+\alpha_{3} \cdot \text { low }_{i}+\alpha_{4} \cdot \text { high }_{i}+\alpha_{5} \cdot \text { highest }_{i}
$$$$
-\beta_{1} p_{i, t-1}-\beta_{2} \cdot \operatorname{rail}_{i} \cdot p_{i, t-1}-\beta_{3} \cdot \operatorname{rail}_{i} \cdot p_{i, t-1}+\varepsilon_{i, t}^{(5)} .
$$

Parameters, with the exception of $\alpha_{1}$ (see column 5 in Table 1 ), are highly significant as well, and the railroad-related variables bear the expected sign. Finally, column 6 in Table 1 shows the estimation of a new model. This model, although similar to model (5), has a common constant term for each state. Convergence results might be biased because of the inclusion of fixed effects in the panel regression [as in model (4) and (5)]. However, after comparing results in columns 4, 5 and 6, we may disregard this possibility and feel more confident about the robustness of our main conclusions: the existence of corn prices converge across states and railroads played a significant and positive role in increasing the speed of such process.

\subsection{Interpretation of results}

The speed of convergence of those states with railroads in 1884 more than doubled that of the states without them. In those states where the construction of railroads took place between 1885 and 1910, convergence speed was positively affected although to not so much. Railroads were then instrumental in the process that eventually put an end to the traditional fragmentation of the Mexican corn market into multiple small units.

Our picture is contradictory with Kuntz (1999b). She claims that the most expensive agricultural products -i.e., coffee, sugar, tobacco- had a very high "tolerance" to transport costs while the opposite applies to the cheapest ones, corn in particular. This distinction seems to be reasonable. The problem is that her "pessimistic" conclusion on the extent to which Mexican railroads contributed to corn market integration is based on an exercise in which it is assumed that agricultural products travel along 400 kilometers before reaching the market place. In our opinion, this assumption is doubtful. On the one hand, market integration would rather operate as a complex interaction within an interconnected network than as movements along a line. According to Roehner (1994), interdependence between European wheat markets in the 19th century took place through "un effet contagion de proche en proche". In their study on the Castilian wheat market in the $18^{\text {th }}$ century, Llopis and Jerez (2001) found that grain could not be transported between distant locations. However they highlight that information had a widespread circulation within the regional market. The integration of two distant markets (A and B) does not imply sending physically corn from A to B, but just that the two points are interconnected within the same commercial network (i.e., A and B may receive corn from a third market or they may exchange just information). On the other hand, it is empirically questionable whether corn came to the Mexican capital city and main market from such a long distance. Thus, this assumption overestimates transport costs while underestimating the "tolerance" of corn to such costs.

Some findings obtained from the analysis of the cross-correlation of residuals time series from the fixed effect model are consistent with this conception of market integration as a complex process. They also reveal the "importance of distance". Shock transmission in corn prices turns to be especially intense within the group of states formed by Aguascalientes, Guanajuato, Michoacán, Mexico, Federal Dis- 
trict, Puebla and Tlaxcala and is generally weak between central and peripheral states. Another interesting pattern is also perceptible: in the centre as well as in the periphery, correlations between neighboring states are quite often high and significant. Thus, a certain picture that makes sense in geographical -hence, arguably also economic- terms emerges in the form of compact groups of states interconnected through shocks: Campeche and Yucatan; Aguascalientes, Guanajuato, Federal District, Mexico and Morelos; Baja California and Sonora; Chiapas and Campeche; Tamaulipas, Coahuila and San Luis Potosi; Durango and Jalisco; Michoacan and Mexico; Guanajuato and Jalisco; Hidalgo and Mexico; Tamaulipas and Veracruz) ${ }^{24}$

Additionally, an important fact has not been taken into account in Kuntz's exercise. Certainly, coffee and corn are different in terms of price. But they also differ in a very important respect. Coffee is mainly a commercial product while corn still maintained -as Kuntz (1999b) recognizes- much of its traditional character as the subsistence crop. Therefore it is only reasonable to find out that the percentage of the Mexican coffee production (60\%) being transported through railroads was higher than that of corn $(20 \%)$. However this contrast does not suffice to cast well-founded doubts about the existence of an increasingly integrated market for corn in Porfirian Mexico. An important share of corn production never entered the market place because it was kept by farmers for self-consumption. Functionally, Mexican corn production -and also consumption, under the realistic assumption of no imports in ordinary years- might be divided into part $\mathrm{C}$ (commercial) and part $\mathrm{S}$ (subsistence). We do not know for sure but probably C was smaller than S in either 1885 or 1908 although the difference decreased in the course of time. ${ }^{25}$ In any case, the said $20 \%$ of total production estimated by Kuntz (1999b) actually represented a much higher percentage (probably a far from negligible $40 \%$ or more) of the commercial production of corn. Obviously, the $\mathrm{C} / \mathrm{S}$ ratio widely differed in value across states, depending on the respective agricultural and economic conditions. It was certainly to feed the relatively small share of Mexican non-agricultural population (37,5\%

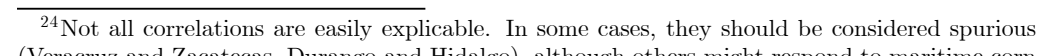
(Veracruz and Zacatecas, Durango and Hidaloo), although others might respond to maritime corn trade (Baja California and Chiapas; Tepic, Colima and Guerrero).

${ }^{25}$ As shown by the simple fact that the rate of growth of the quantity of corn transported through railroads between 1894 and 1907 (1,85\% per year) exceeds that of the production $(1,13 \%)$ [Kunts (1999b)]. If we include an earlier period in the comparison, this difference is even greater, as suggested by the performance of the Ferrocarril Central Mexicano: 26,000 metric tons in 1884 compared with 188,000 in 1907 [Kuntz (1995a)]. of total employment, according to the 1910 census). ${ }^{26}$ As corn imports are of no importance in ordinary years, domestic production and consumption are necessarily balanced. Therefore, if Kuntz's "pessimistic" view is accepted, we are confronted with a puzzle: the distribution of Mexican corn production across states -see Map 6clearly shows that some of them were net producers while other were net consumers in a normal year like $1907 .^{27}$

\section{INSERT MAP 6 ABOUT HERE}

A further result is also achieved by this exercise -see Map 6. Some regional centres of production emerge (Chihuahua in the North; Tamaulipas in the North-East; Guanajuato, Mexico, Michoacan, etc. in the Centre; Campeche in the Gulf). This picture is consistent with the idea that market integration in a country so vast, geographically fragmented and backward as Porfirian Mexico, creates a centre-periphery structure. The exercise also shows that the surplus produced in Chihuahua, Tamaulipas and Campeche is not sufficient to match the deficit of the surrounding and scarcely populated states. This situation contrasts with the massive surplus in a compact group of central, densely populated states. Therefore the integration of the corn market at supra-regional level is necessary to explain the geography of surplus and deficit depicted in Map 6.

\section{Conclusions and extensions}

Corn prices substantially differed across Mexican regional markets before 1885 . However, between 1885 and 1908, the dispersion of corn prices decreased significantly. The least implausible explanation for price convergence is market integration. This process was not limited to some agricultural products or regions.

Applying panel data techniques, conditional convergence in corn prices is confirmed. Different groups of states present different steady states. Moreover, with only a few exceptions, after grouping steady states, a centre-periphery geography emerges, in which most of "close-to-average" regions (i.e., Queretaro, Nuevo Leon, ${ }^{26}$ Besides, especially for this minority of the Mexican population, it is likely that other agricul-
tural products substituted for corn. [Coatsworth [1990)].

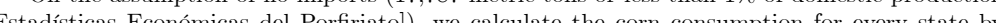
multiplying population by 2.29 (resulting from dividing total domestic production among Mexican population). Net surplus or deficit for every state equats contion minus production. In Map 
San Luis Potosi, Guerrero, Aguascalientes, etc.) occupy central -loosely defined- positions and "far-from-average" regions those in the periphery (i.e., Tepic, Campeche, Colima, Veracruz, Chiapas, Baja California, Sonora, etc.). Convergence speeds of the Mexican regions are also far from being identical. Once again, a centre-periphery spatial structure emerges clearly: convergence speed decreases almost continuously when moving from the central area (Hidalgo, Michoacan, Mexico, Morelos, and Tlaxcala) to the periphery (Campeche, Yucatán, Baja California, Sinaloa and Sonora). However, as can be seen, the two geographies are not identical. We have also found evidence of a significant and positive influence of railroads on the convergence speeds of the states. Conversely, no significant relationship between railroads and steady states has been found.

Although still incomplete at the eve of the Mexican Revolution, market integration of regional corn markets substantially increased during the Porfiriato. Circa 1910, it was higher than in the years before the building of the railroad network. Under the assumptions that increasing integration of corn market was impossible in the absence of some specialization at state or regional levels, and that specialization implies higher productivity, our results might lead to a more optimistic reconsideration of the growth of the non-export agrarian sector during the Porfiriato.

Mexico does not turn to be an exception in the international panorama of the late $19^{t h}$ and early $20^{\text {th }}$ centuries among those countries that took part in the economic globalization of the period. It would be interesting to examine the Mexican case through a comparative approach.

An interesting extension would be to test whether the improvement in transportation brought about by railroads was or not complemented by other parallel mprovements in the conventional means. It is our guess that probably railroad did not only contribute to market integration directly but also indirectly through the stimulation of complementary gains in the efficiency of traditional means of transportation.

The heterogeneity of the convergence process at state level deserves further research. Differences in government regulations on the corn market across states and over time seem worth being explored. As to the heterogeneity in the steady states, a preliminary overview suggests that geography (altitude, climate, soils, distance to relevant locations, etc.) and supply-demand factors contribute to the explanation, at least partially.

Given the available evidence with respect to corn, it is very likely that convergence in prices of other agricultural products has been earlier and faster. Testing this hypothesis within a similar analytical framework is an interesting task that might contribute to a full assessment of the general process of agricultural market integration in Porfirian Mexico.

Analyzing the process of agricultural market integration during the revolutionary and post-revolutionary periods would offer not only an useful long-term perspective on this important issue but also some insights into the equally relevant determination of the economic consequences of the political instability prevailing in Mexico. This extension might or might not reinforce a certain revisionism, at least partially, of the traditional interpretation of the Revolution and its aftermath. 


\section{References}

[1] BARRO, R. J. y SALA-I-MARTIN, X. (1990): "Economic Growth and Convergence Across the United States", NBER Working Paper, $\mathrm{n}^{\circ} 3419$.

[2] - (1992): "Convergence", Journal of Political Economy, 100, (2), 223-251.

[3] - (1995): "Economic Growth", McGraw-Hill, Nueva York.

[4] BASSOLS, A. (1998), "Geografía económica de México", Editorial Trilla, Mexico, etc.

[5] BUSHNELL, D. and MACAULAY, N. (1989): "El Nacimiento de los países Latinoamericanos", Nerea, Madrid.

6] CALDERON, F. (1965), "Los Ferrocarriles", COSIO y VILLEGAS, D. (ed.), Historia Moderna de México, Vol VII. El Porfiriato. Vida Económica. Primera Parte, Hermes, México, pp. 483-634.

[7] CERRUTI, M. (1992): "Burguesía, capitales e industria en el norte de México", Alianza Editorial, etc., México.

[8] COATSWORTH, J. (1979): "Indispensable Railroads in a Backward Economy The Case of Mexico", Journal of Economic History, XXXIX, 4, pp. 939-960.

[9] COASTWORTH, J. (1984): "El impacto económico de los ferrocarriles en el Porfiriato. Crecimiento contra desarrollo", Era, México.

[10] - (1990): "La producción de alimentos durante el Porfiriato", Alianza Editorial Mexicana, México.

[11] CHEVET, J. M. (1996), "National an Regional Corn Markets in France from the Sixteenth to the Nineteenth Century", The Journal of European Economic History, 25, 3, 681-703.

[12] EL COLEGIO DE MEXICO (1960): "Comercio exterior de México, 18771911", El Colegio de México, México.

[13] ERJNAES, M. and PERSSON, K. G. (2000): "Market Integration and Transport Costs in France, 1825-1903: A Threshold Error Correction Approach to the Law of One Price", Explorations in Economic History, 37, 149-173.
14] ESQUIVEL, G. (1999): "Convergencia regional en México, 1940-1995", El Trimestre Económico, LXVI, 4, pp.725-761.

15] FINDLAY, R. and O'ROURKE, K. (2001): "Commodity Market Integration, 1500-2000", NBER Working Paper 8579.

16] FLORESCANO, E. (coord.) (1983): "Atlas histórico de México, Siglo XXI", México, etc.

17] GRUPO DE ESTUDIOS DE HISTORIA RURAL (1980): "Los precios del trigo y la cebada en España, 1891-1907", Banco de España, Madrid.

[18] HABER, S. (1997): "Introduction: Economic Growth and Latin American Economic Historiography", HABER, S. (ed.), How Latin America Fell Behind, Stanford University Press, Stanford, 1-33.

[19] HAUSMAN, J. A. (1978): "Specification Tests in Econometrics", Econometrica, $46,1251-1271$.

[20] HSIAO, C (1986): "Analysis of Panel Data”, Econometric Society Monographs, Cambridge University Press.

21] HURD, J. (1975): "Railways and the Expansion of Markets in India, 18611921", Explorations in Economic History, 12, pp. 263-288.

22] INSTITUO NACIONAL DE ESTADISTICA, GEOGRAFIA E INFORMATICA (1985): "Estadísticas históricas de México", INEGI, México.

23] KUNTZ, S. (1995a): "Empresa extranjera y mercado interno", El Colegio de México, México.

[24] - (1995b) "Mercado interno y vinculación con el exterior: el papel de los ferrocarriles en la economía del Porfiriato", Historia Mexicana, XLV, 1, pp. 39-66.

[25] - (1996), "Ferrocarriles y mercado: tarifas, precios y tráfico ferroviario en el Porfiriato", KUNTZ, S. and RIGUZZI, P. (coords.), Ferrocarriles y vida económica en México, 1850-1950, El Colegio Mexiquense, etc., Mexico.

[26] - (1999a): "Los ferrocarriles y la formación del espacio económico en México, 1880-1910", KUNTZ, S. and CONNOLLY, P. (coords.) Ferrocarriles y obras públicas, Instituto Mora, etc., México, pp. 105-137. 
[27] - (1999b): "Ferrocarriles y mercado de productos agrícolas en el Porfiriato. El impacto de las tarifas ferroviarias", MENEGUS, M. (coord.) Dos décadas de investigación en historia económica comparada en América Latina, El Colegio de México, etc., México.

[28] LLOPIS, E. and JEREZ, M (2001): "El mercado de trigo en Castilla y León, 1691-1788: arbitraje espacial e intervención”, Revista de Historia Agraria, 2001 $25, \mathrm{pp}$.

[29] MAURER, N. (1999): "Progress without Order: Mexican Economic History in the 1990s", Revista de Historia Económica, XVII, special number, pp. 13-36.

[30] METZER, J. (1974): "Railroad Development and Market Integration: The Case of Tsarist Russia", Explorations in Economic History, XXXIV, 3, 529550

[31] O'ROURKE, K. and WILLIAMSON, J. (1999): "Globalization and History", The Mit Press, Cambridge, etc.

[32] -(2000), "When Did Globalization Begin?", NBER Working Paper 7632.

[33] PERSSON, K. G. (1999): "Grain Markets in Europe, 1500-1900: Integration and Deregulation", Cambridge University Press, Cambridge.

34] RIGUZZI, P (1999): "Mercados, regiones y capitales en los ferrocarriles de propiedad Mexicana, 1870-1908", en KUNTZ, S. y CONNOLLY, P. (coords.) Ferrocarriles y obras públicas, Instituto Mora, etc., México, 39-70.

[35] ROEHNER, B. M. (1994): "Les mecanismes d'interdépendance spatiale entre marchés de blé au XIXe siècle", Histoire, Economie et Societé, 2, 343-394.

[36] ROTHENBERG, W. (1981): "The Market and Massachusetts Farmers, 17501855", Journal of Economic History Review, XLI, 2, 283-314.

[37] SANCHEZ ALBORNOZ, N. (1975), "Los precios agrícolas durante la segunda mitad del siglo XIX. Vol. I: Trigo y Cebada", Banco de España, Madrid.

[38] SUMMERHILL, W. (1997): "Transport Improvements and Economic Growth in Brazil and Mexico", HABER, S. (ed.) How Latin America Fell Behind, Stanford University Press, Stanford, pp. 93-117.
39] UNITED STATES DEPARTMENT OF AGRICULTURE (1917): "Bulletin", 
Table Appendix

Table 1: Estimation results of alternative convergence models.

\begin{tabular}{|c|c|c|c|c|c|c|}
\hline & $\begin{array}{c}1) \\
\begin{array}{c}\text { Non-fixed } \\
\text { effect }\end{array}\end{array}$ & $\begin{array}{l}\text { (2) } \\
\text { Fixed } \\
\text { effect }\end{array}$ & $\begin{array}{c}\text { Dummy } \\
\text { group }\end{array}$ & $\begin{array}{c}(4) \\
\text { Fixed effect, } \\
\text { Dummy } \\
\text { Railroad }\end{array}$ & $\begin{array}{c}(5) \\
\text { Dummy group } \\
\text { Dummy } \\
\text { Railroad } \\
\end{array}$ & $\begin{array}{c}(6) \\
\text { Non-fixed Effect } \\
\text { Dummy } \\
\text { Railroads }\end{array}$ \\
\hline Beta & 0,31 & 0,54 & 0,49 & 0,24 & 0,29 & 0,15 \\
\hline Beta*rail0 & -- & -- & -- & 0,51 & 0,38 & 0,32 \\
\hline Beta*rail1 & - & - & - & 0,29 & $0,15^{(* *)}$ & $0,13\left(^{(* * *}\right)$ \\
\hline alpha & $-0,01\left(^{*}\right)$ & -- & $-0,01\left(^{(*)}\right.$ & -- & $-0,01\left(^{*}\right)$ & $-0,02$ \\
\hline lowest & -- & - & $-0,23$ & -- & $-0,19$ & -- \\
\hline low & -- & -- & $-0,09$ & -- & $-0,12$ & -- \\
\hline high & -- & -- & 0,06 & -- & 0,07 & -- \\
\hline highest & -- & -- & 0,16 & -- & 0,13 & -- \\
\hline$R^{2}$ & 0,16 & 0,27 & 0,25 & 0,31 & 0,28 & 0,17 \\
\hline$R^{2}$-adjsuted & 0,16 & 0,24 & 0,24 & 0,27 & 0,27 & 0,17 \\
\hline D-W & 2,09 & 1,94 & 1,96 & 1,92 & 1,94 & 2,0 \\
\hline
\end{tabular}

The rest of parameters are significative at $1 \%$

In general, the normality Jarque-Bera, the uncorrelated and homoskedastic time-frequeney te Covariance
Table 2: Corn Relative Prices (Mexico 1885-1908)

\begin{tabular}{|l|l|l|}
\hline Grouping States accordingly to estimated steady-state levels \\
\hline Type of steady-state & Group name & Name of States \\
\hline
\end{tabular}

\begin{tabular}{|l|c|l|}
\hline Type of steady-state & Group name & Name of States \\
\hline \hline Significative negative and lowest & Lowest & Tepic, Campeche, Colima \\
\hline Significative negative and low & Low & $\begin{array}{l}\text { Tabasco, Zacatecas, Jalisco, } \\
\text { Michoacan, Morelos, Guanajuato }\end{array}$ \\
\hline Significative equal to cero & Cero & $\begin{array}{l}\text { Queretaro, Nuevo Leon, San Luis } \\
\text { Potosi, Guerrero, Aguas Caliente, } \\
\text { Tamaulipa, Sinaloa, Durango, } \\
\text { Tlaxcala, DF, Mexico, Oaxaca }\end{array}$ \\
\hline Sinificative positive and high & High & $\begin{array}{l}\text { Yucatan, Coahuila, Puebla, Hidalgo, } \\
\text { Chihuahua }\end{array}$ \\
\hline Significative positive and highest & Highest & $\begin{array}{l}\text { Veracruz, Chiapas, Sonora, Baja } \\
\text { California }\end{array}$ \\
\hline
\end{tabular}


Maps Appendix

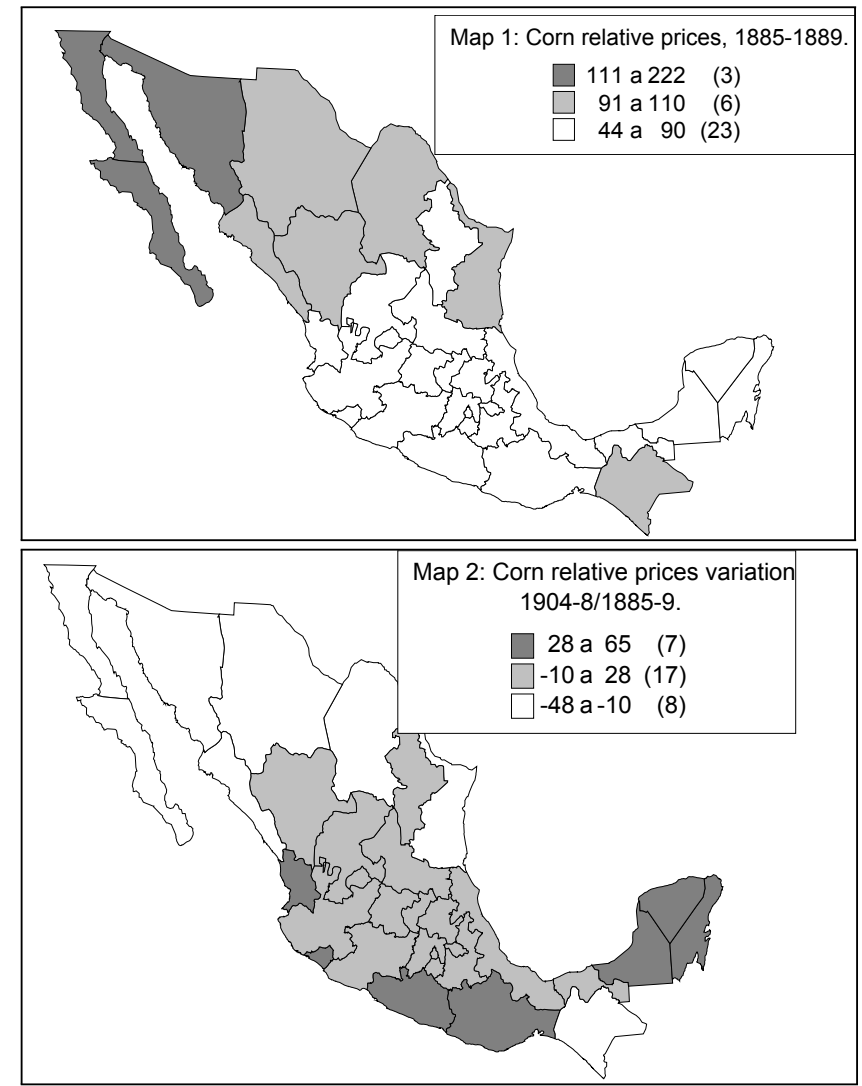

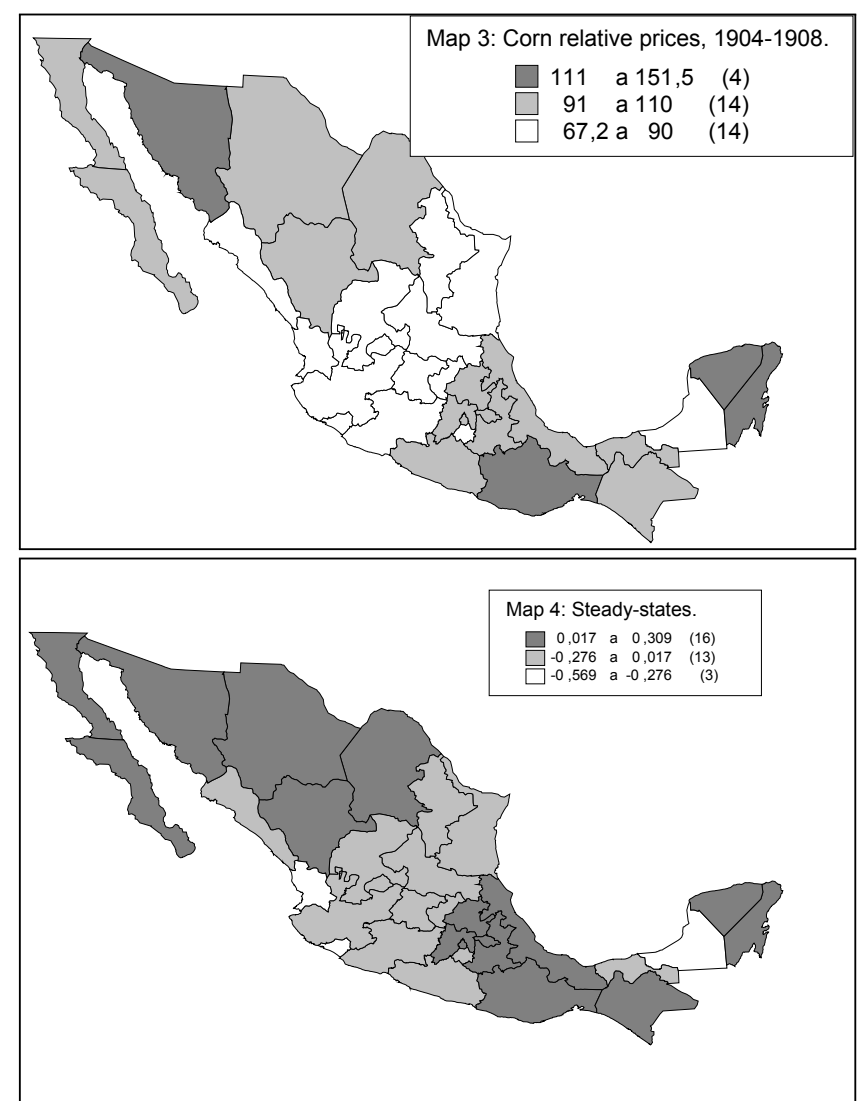

28 


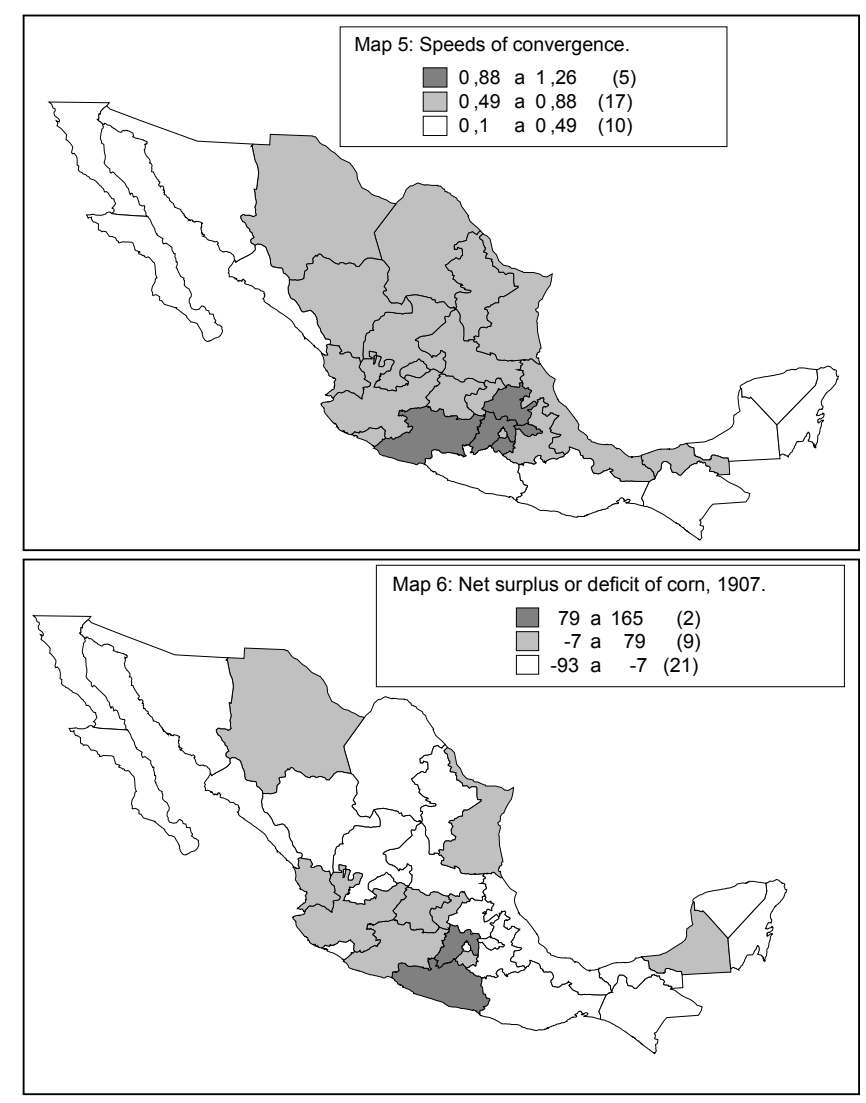

Figures Appendix

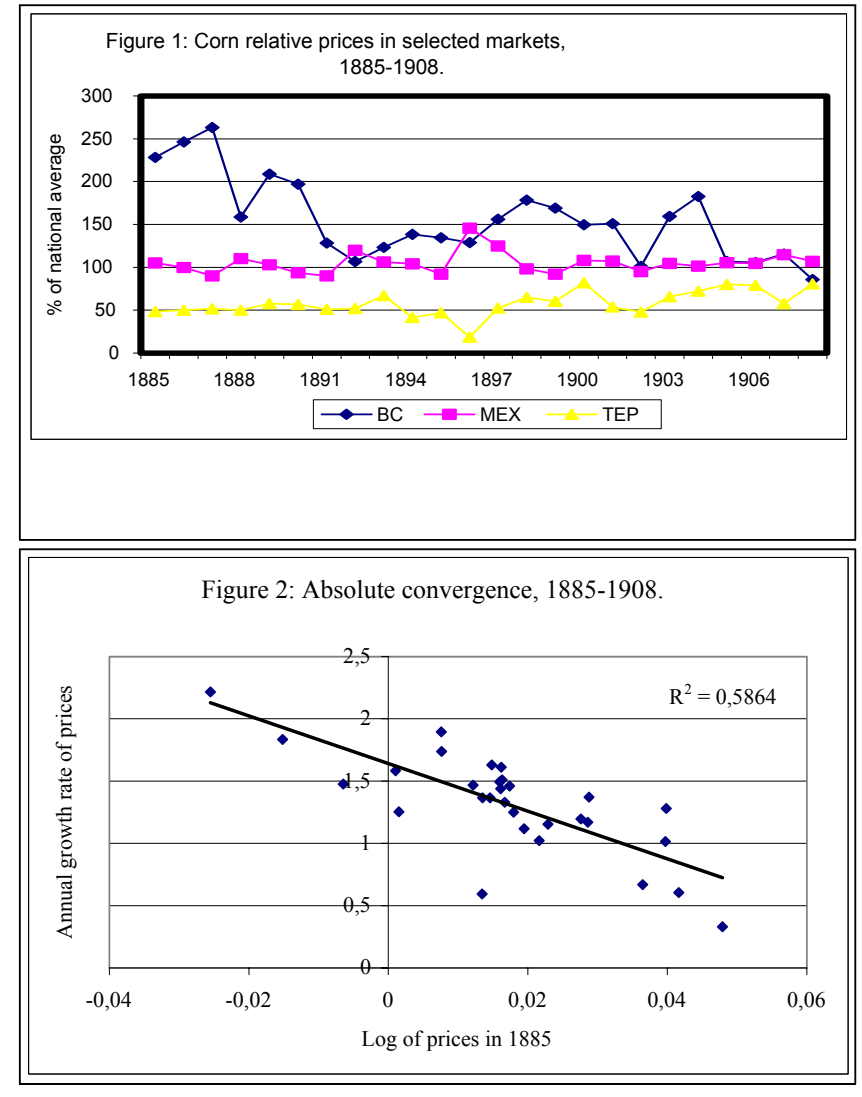



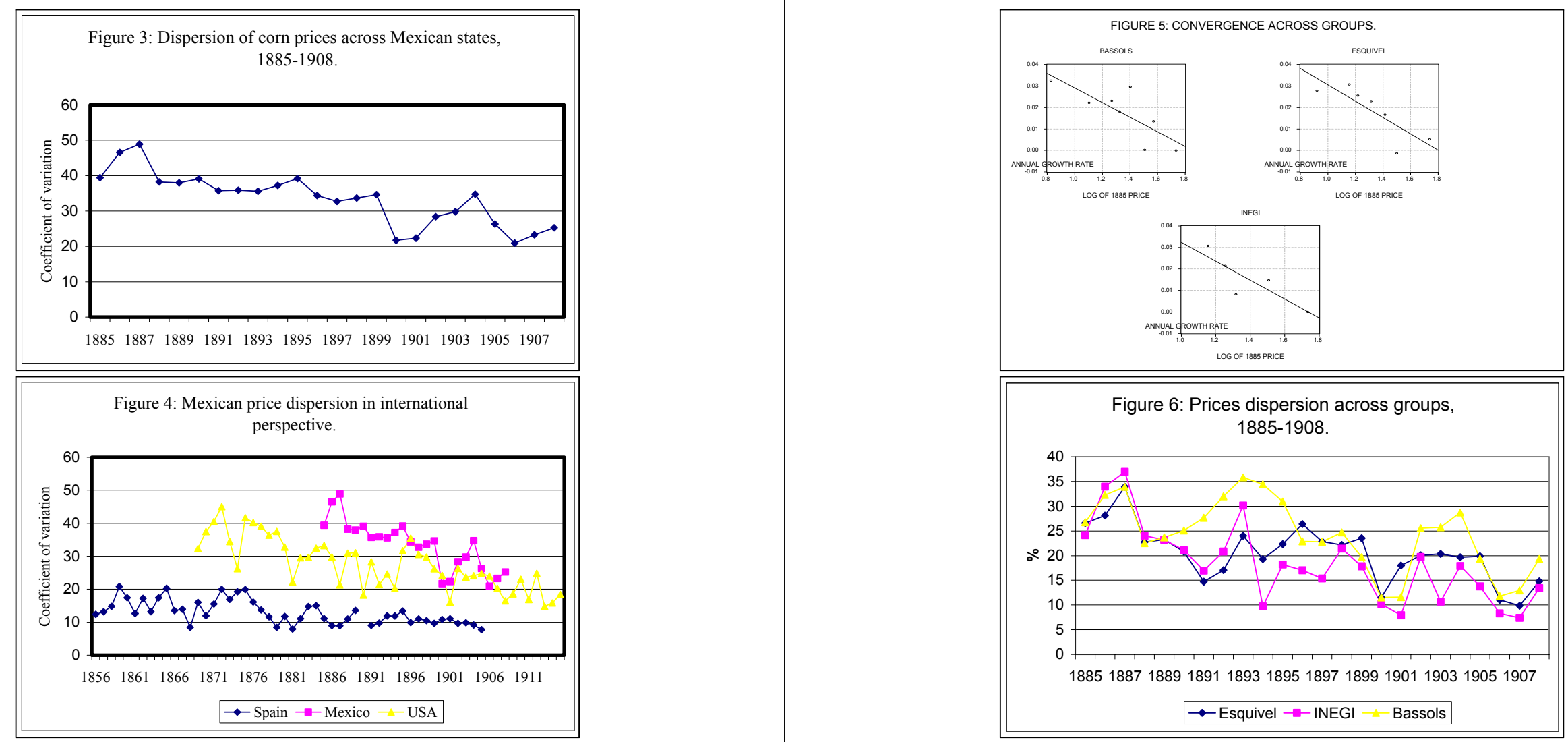